\section{The American Association for Thoracic Surgery}

\section{Announcement of 2007 Annual Meeting}

$\mathrm{T}$ The Eighty-seventh Annual Meeting of The American Association for Thoracic Surgery will be held May 5-9, 2007, in Washington, D.C., at the Washington Convention Center. The meeting of the Association is open to all physicians. House Officers and Fellows will be admitted without payment of a registration fee upon presentation of a letter from their Chief of Service either during preregistration or at the time of registration. Nonmember physicians are required to pay a $\$ 250$ preregistration fee up to March 24, 2007. After that date a registration fee of $\$ 350$ will be required. Members, nonmember physicians, and invited speakers will have the privilege of discussing papers.

\section{Requests for Preregistration Forms and Hotel Reservations}

Information on the 2007 Annual Meeting, including registration, hotel accommodations, and the social program, will be available in December 2006. Requests should be forwarded directly to:

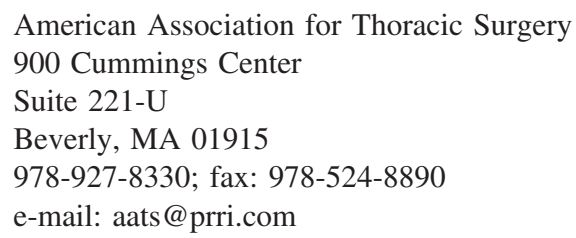

Registration and hotel information will be available on our Web site at www.aats.org.

\section{Call for Abstracts}

Authors submitting abstracts for the 2007 Annual Meeting must use electronic submission. Abstracts submitted electronically for consideration for presentation at the 2007 meeting must be received on or before October 10, 2006. Abstracts received after the deadline will not be considered by the Program Committee. The work must not have been presented or reported elsewhere.

\section{Electronic Submission}

Deadline for submission is October 10, 2006. Please submit your abstract via the World Wide Web. All abstract submissions must be in the structured format as required by The Journal of Thoracic and Cardiovascular Surgery. The structured abstract is to contain the following major headings: Objective(s), Methods, Results, and Conclusions, and it should clearly reflect the content of the completed paper. No reference should be made on the abstract to the names or institutions of the authors.
Receipt of each abstract will be acknowledged by e-mail. Notification of the decision of the Program Committee will be distributed by the end of December 2006.

Essayists selected for the program are reminded that papers presented at the meeting are to be submitted for consideration for publication to The Journal of Thoracic and Cardiovascular Surgery and must be submitted to the JTCVS via the Internet prior to the Annual Meeting. Papers that are selected by the AATS Program Committee may not be presented or published elsewhere prior to the Annual Meeting in 2007.

\section{Walton Lillehei Resident Forum}

The C. Walton Lillehei Resident Forum will be held on Sunday, May 6, 2007. Made possible through an educational grant from St Jude Medical, the Forum will consist of the presentation of original work by residents in thoracic surgical training programs around the world. Abstracts submitted for the award should follow the guidelines of abstract submission for electronic submission noted above. The abstracts submitted for consideration for this Forum will be evaluated by the Program Committee and eight will be selected for presentation during the forum. Each of the selected authors will receive round-trip travel and accommodations for the duration of the AATS annual meeting. Additionally, one presentation will be selected by the Program Committee to receive the AATS C. Walton Lillehei Residents' Award, a $\$ 5000$ prize. Thoracic Surgery Program Directors are urged to have their residents participate in this Forum.

Abstract Deadline-Abstracts received after the deadline will not be considered

Electronic Submission Only: October 10, 2006

\section{Applications for Membership}

Applications for membership in the Association are available online at www.aats.org no later than November 2006. Applications received after that date are deferred automatically for consideration until the 2008 meeting.

\section{Evarts A. Graham Memorial Traveling Fellowship, 2007-2008}

$\mathrm{T}$ The Evarts A. Graham Memorial Traveling Fellowship was established in 1951 by The American Association for Thoracic Surgery. Administered through the Graham Education and Research Foundation, Fellowship grants support study by young cardiothoracic surgeons from outside North America at sites of their choice within North America and include travel between sites. Goals of the program are to broaden overall training and increase international contacts. Each Fellow should plan to have one primary center for his/her activities where he/she should spend six to nine months. The Fellow should have identified an individual at that center who will act as his/her sponsor and assist in planning the course of study at the host institution and at other institutions. In addition to the primary center, the Fellow is en- 
couraged to plan to spend shorter periods of time at other secondary centers to enhance the Fellowship experience.

Awards are made to surgeons of unique promise who have been regarded as having the potential for later international thoracic surgical leadership. Since the inception of the Graham Fellowship, 54 young surgeons from 27 countries have been named for the Fellowship.

The Fellowship provides a stipend of $\$ 75,000$, a major portion of which is intended for travel expenses incurred when visiting other medical centers. The Fellowship also provides two round-trip coach air fares from the recipient's country to his/her primary center. The dates of the beginning and ending of the Fellowship year should be scheduled to coincide with the Annual Meetings of The American Association for Thoracic Surgery. The Fellow will be introduced at the May 2007 meeting, which will take place at the Washington DC Convention Center in Washington, DC, May 5-9. The Fellow will be expected to provide a written summary of his/her year's experience to the membership prior to its 2008 Annual Meeting, which will take place at the San Diego Convention Center in San Diego, California, May 10-14.

The Fellow should become involved predominantly with observation, consultation, teaching and research at a variety of thoracic surgical training centers during the twelve months. Patient contact will be determined by the sponsoring surgeon and will conform to the regulations and licensing requirements of the state, province, or country in which he/she is studying.

A candidate should have completed his/her formal training in general surgery and in thoracic and cardiovascular surgery, but he/she should not have reached a senior position. Candidates must be sufficiently proficient in English to realize the full benefits of the fellowship. Candidate should not have had extensive clinical training in North America prior to making application, and should be planning to return to their native country following the completion of their fellowship. "Extensive" clinical training shall mean any period of clinical training which exceeds a total of six months in duration.

The online application submission site was available beginning in March 2006 at www.aats.org. All applications must have been submitted electronically via the online application submission site no later than July $\mathbf{1}$. The selected candidate will be notified by November 1 .

\section{Resident Traveling Fellowship, 2006-2007}

$\mathrm{T}$ The American Association for Thoracic Surgery announces the Resident Traveling Fellowship, a program established to broaden the educational experience of residents in their final year of an approved cardiothoracic surgical training program by providing an opportunity to spend up to two weeks at one or more institutions other than their home institution.

A grant of $\$ 5,000$ will be provided to successful applicants to underwrite their travel and living expenses incurred during up to two weeks of training at one or more host institutions. The funds are also intended to provide for roundtrip travel and four nights' accommodations at the annual meeting of the Association sched- uled for May 5-9, 2007 in Washington DC. The fellowship must be completed prior to March 31, 2007.

Applicants must have the approval of their home and prospective host institutions. Candidates must submit an online AATS application and include a one-page outline of what they hope to accomplish during their training. Additionally, award recipients must agree to submit a summary report to the membership of the association within thirty days after the completion of their training.

The candidate must be a North American resident in his or her final year (during 2006-07) of an approved cardiothoracic surgical training program.

Applications must have been completed and submitted online at www.aats.org by July $\mathbf{1}$. The selected candidates were notified by September 30 to accommodate travel between October 1, 2006 and March 31, 2007.

\section{Second Dwight Harken Research Scholarship, 2007-2009}

$\mathrm{T}$ The American Association for Thoracic Surgery announces the Second Dwight Harken Research Scholarship to provide an opportunity for research, training and experience for North American surgeons committed to pursuing an academic career in cardiothoracic surgery. The scholarship will be funded by the Association and administered by the Graham Education and Research Foundation.

The research program must be undertaken within the first three years after completion of an approved cardiothoracic residency. Applications for the scholarship may be submitted during the candidate's final year of cardiothoracic residency or during his or her first two years in an academic position. The duration of the scholarship is to be two years.

The yearly stipend shall be $\$ 75,000$ paid to the host institution. In addition, a grant of $\$ 5,000$ per year shall be made for support of research supplies, travel, and other legitimate academic expenses of the scholar. The application consists of three components:

1. The candidate must submit a proposal for the research to be undertaken and a statement of career plans and how the research activity will relate to the candidate's academic career.

2. The director of the laboratory in the institution at which the research will be performed shall submit an endorsement of the proposal and indicate the facilities and degree of support available for the candidate's research.

3. The chairman of the candidate's department shall submit his or her endorsement of the proposal and indicate the willingness of the institution to provide an academic appointment for the candidate upon completion of the scholarship.

The application and its components must have been submitted online at www.aats.org by July 1. Announcement of the award will be made by the president of the American Association for Thoracic Surgery by December 15. The scholarship will begin July 1, 2007. Following completion of the two-year program, the scholar shall submit a written report of his/her research activities to the membership of the Association. 